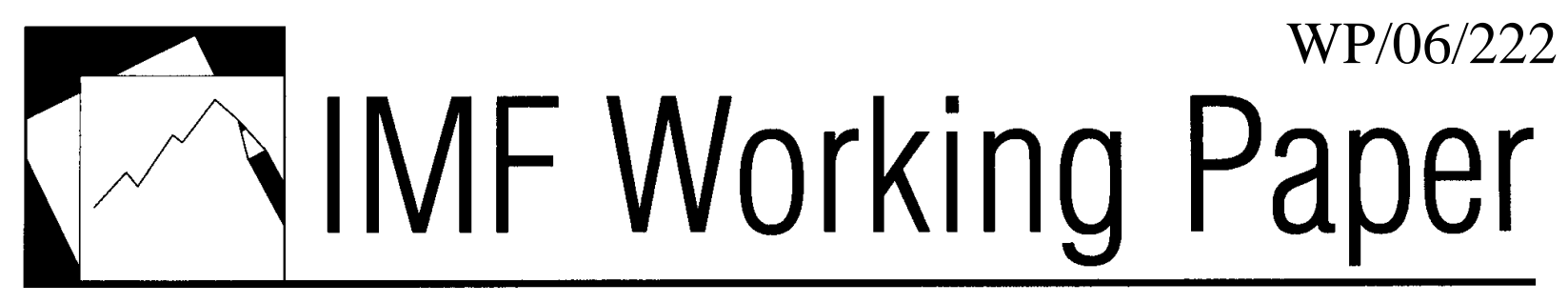

\title{
Economic and Political Determinants of Tax Amnesties in the U.S. States
}

\author{
Eric Le Borgne
}





\title{
IMF Working Paper
}

Fiscal Affairs Department

\section{Economic and Political Determinants of Tax Amnesties in the U.S. States}

\author{
Prepared by Eric Le Borgne
}

Authorized for distribution by Michael Keen

September 2006

\begin{abstract}
This Working Paper should not be reported as representing the views of the IMF. The views expressed in this Working Paper are those of the author(s) and do not necessarily represent those of the IMF or IMF policy. Working Papers describe research in progress by the author(s) and are published to elicit comments and to further debate.
\end{abstract}

This paper revisits earlier studies on the determinants of tax amnesties. The novel findings are (i) amnesties are more likely to be declared during fiscal stress periods, and (ii) political factors significantly affect the introduction and timing of amnesties. In particular, the paper empirically disentangles opposite theoretical effects to show that governors perceive amnesties as another revenue source (rather than a tax increase alternative). Finally, supporting evidence shows that by breaking horizontal equity, amnesties might be perceived as unfair: a significant correlation exists between governors who lost their reelection bids and the introduction of a tax amnesty during their election years.

JEL Classification Numbers: H20, H26, H29

Keywords: Tax amnesty, Gubernatorial elections, Cox model

Author's E-Mail Address: eleborgne@imf.org

\footnotetext{
${ }^{1}$ I would like to thank Michael Keen and seminar participants at the 2005 National Tax Association conference for valuable comments. A version of this paper is forthcoming in the National Tax Association Proceedings.
} 


\section{Contents}

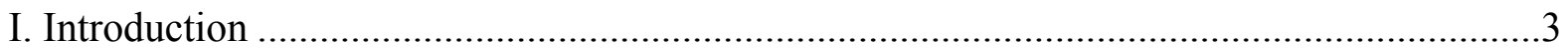

II. Methodology: A Discrete-Time Duration Model....................................................6

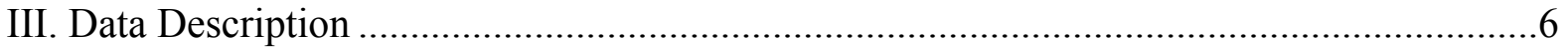

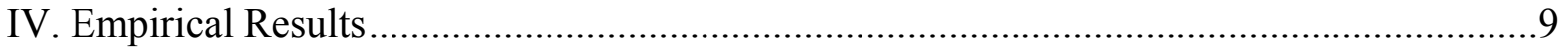

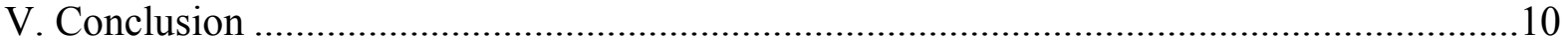

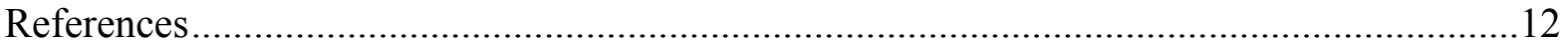

Tables

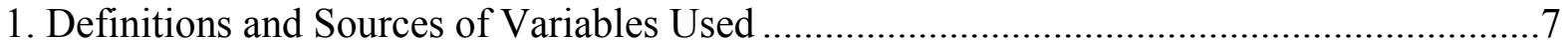

2. Summary Statistics of Estimation Sample 1/_............................................................

3. Model for Time Waited Before Initiating a State Tax Amnesty .....................................10

Figures

1. U.S. States: Number of Tax Amnesties Per Year, 1982-2004 ..........................................4 


\section{INTRODUCTION}

Almost all U.S. states have offered an amnesty program since $1980^{2}$; some have offered several, often related to the same taxes. ${ }^{3}$ These tax amnesties differ widely in terms of coverage, tax types, and incentives offered. Tax amnesties have been designed to cover all taxpayers, broad categories of taxpayers (e.g., small taxpayers, identified delinquent taxpayers), or tax types (e.g., corporate income tax, sales tax). Amnesties differ with regard to what is forgiven (e.g., interest, penalties, tax liabilities, criminal prosecution). In some cases, only the penalty and interest components of the liability - which often account for the bulk of the overall tax debt - may be forgiven, partially or fully. In other cases, the basic tax liability itself may be reduced. Alternatively, the tax authority may establish a repayment schedule under which interest and penalties stop accruing altogether, or interest may be assessed at something less than market rates. Such a rescheduling is still an amnesty, as the net present value of the debt is reduced.

While infrequent, state tax amnesty programs tend to be highly clustered over time. At the level of the U.S. states from 1980 to 2004, the (unconditional) probability that a state will introduce a tax amnesty program in a given year is 6.5 percent. However, as Figure 1 immediately reveals, tax amnesties are highly clustered in time. Following an initial wave in the mid-1980s, they (timidly) reappeared some ten years later, and then became fairly common at the turn of the century.

This paper analyzes the underlying determinants of state tax amnesty programs. The two primary reasons for introducing tax amnesties ${ }^{5}$ are (i) to raise revenue in the short-term, and/or (ii) to increase compliance (e.g., by encouraging taxpayers to declare and pay previously undeclared tax, file tax returns, or register to pay taxes, so as to increase revenue and horizontal equity in the medium term). Within the revenue-raising motive, the introduction of tax amnesties has also been strongly motivated by the desire of the tax authorities to quickly obtain windfall revenue gains.

\footnotetext{
${ }^{2}$ A tax amnesty can be defined as a program that provides for a reduction in real terms of taxpayers' declared or undeclared tax liabilities as established by law.

${ }^{3}$ Forty-two states have offered tax amnesty programs. Those with multiple programs include Louisiana (four), Arizona (three), Connecticut (three), Florida (three), Massachusetts (three), Missouri (three), New Jersey (three), and New York (three). From 1980 to 2004, a total of 78 amnesty programs have been introduced by U.S. states.

${ }^{4}$ This time-clustering phenomenon is also present across countries. See Franzoni (1995) or Torger and Schaltergger (2005) for a review of recent tax amnesties around the world.

5 The literature on tax amnesty extends the literature on tax compliance that started with Allingham and Sandmo (1972). (See Andreoni, Erard, and Feinstein (1998) for a recent review of that literature.) Early contributions to the tax amnesty literature include Alm and Beck (1990), Andreoni (1991), Malik and Schwab (1991), Stella (1991), and Graetz and Wilde (1993).
} 
Figure 1. U.S. States: Number of Tax Amnesties Per Year, 1982-2004

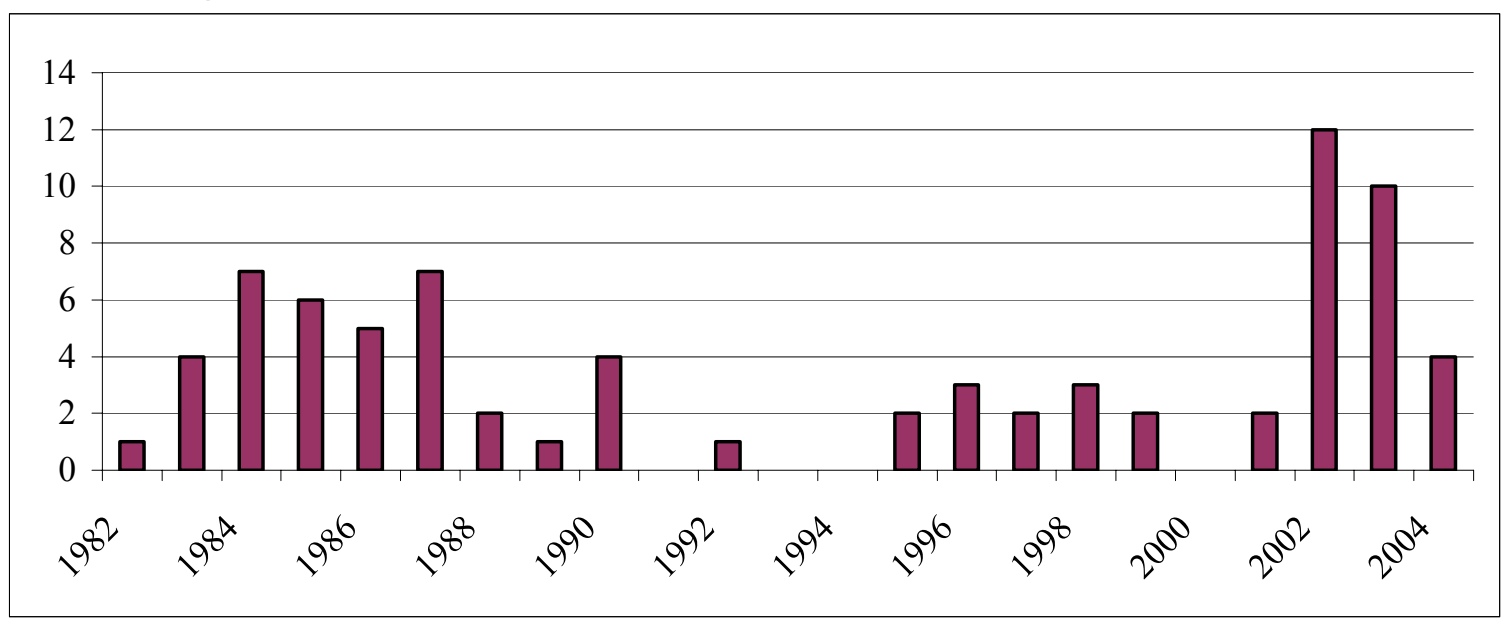

Although the reasons for "successful" (in terms of immediate gross revenue yield) tax amnesties are well understood ${ }^{6}$ in both the economic literature and by practitioners (increasing revenues and compliance), the determinants of the introduction of a tax amnesty program are far less so. ${ }^{7}$ In an important early study, Dubin, Graetz, and Wilde (1992) analyzed precisely this question. They investigated two potential rationales for introducing tax amnesties: the first is the idea that a state would initiate a tax amnesty if it expects the amnesty program to produce a significant (gross) revenue yield (the "yield" motive); and the second is the idea that a state would introduce an amnesty in times of fiscal duress - that is, an amnesty is one source (along with raising taxes) for increasing revenue collection during a recessionary period (the "fiscal stress" motive). They find that the most important reason for

\footnotetext{
${ }^{6}$ Allowing detected tax evaders (also known as accounts receivable) to participate in a tax amnesty is by far the major determinant of the (gross) revenue yield of tax amnesties. (Of the $\$ 6.6$ billion in total gross amnesty revenue collected by the states during 1980-2004, 92 percent were from programs that allowed taxpayers with accounts receivables to participate.) The other key determinant of (gross) revenue yield is the coupling of a tax amnesty program with increased (and advertised) tax administration detection and enforcement capacity (e.g., Alm, McKee, and Beck, 1990).

${ }^{7}$ We should note, however, that immediate gross revenue yield - although often used as a benchmark for evaluating the "success" of an amnesty - only captures one aspect (gross short-term gain) of what would be a successful tax amnesty. (Net short-term gain, long-term compliance, and revenue effects are not taken into account.) The empirical evidence on the long-run revenue effect from states' amnesty cum increased enforcement strategy is inconclusive. Joulfaian (1988), studying Massachusetts amnesty program, finds that chronic nonfilers as well as filers who underreport tax are not attracted by tax amnesties. Alm, McKee, and Beck (1990), in an experimental study, find that compliance decreases after amnesties (on their own), but rises if amnesties are combined with tighter enforcement. Alm and Beck (1993) find that the 1985 Colorado tax amnesty had no long-run effect on tax revenues (either their level or growth rate). Christian, Gupta, and Young (2002) find, using data on subsequent filing from the Michigan income tax amnesty, that the additional revenue raised from these taxpayers is marginal (around 0.1 percent of the state's personal income tax revenues).
} 
introducing a tax amnesty is its expected revenue yield, while a state's "fiscal stress" is not a significant factor. Earlier studies (e.g., Leonard and Zeckhauser (1987)) had found evidence of a fiscal stress effect on a much more limited sample than Dubin, Graetz, and Wilde (1992) (hereinafter referred to as DGW) did.

This paper revisits the same question as DGW: what are the causes of state tax amnesties? Revisiting this question more than a decade later is desirable for the following reasons: first, as described earlier, state tax amnesties tend to come in waves. DGW's analysis was concerned with the 1980s amnesty programs, and the reasons for introducing these might be different from the reasons for the second and third waves of amnesties. Second, our sample is much larger (about twice the size) than that used by DGW, which significantly improves the statistical robustness of our results. (DGW's sample contained 40 tax amnesties.) Third, our econometric modeling of the probability of declaring an amnesty differs from theirs; DGW rely on a parametric duration model which assumes normally distributed hazards - an assumption that is rarely met in survival analysis problems. As Figure 1 earlier showed, state tax amnesties tend to be clustered in time, which would indicate a multimodal, rather than a normal, distribution, thereby violating the normally distributed hazards assumption and significantly affecting the econometric results. Finally, we investigate the role that political factors might have in the timing and introduction of tax amnesties - as opposed to the purely economic factors considered in DGW. ${ }^{8}$

Political factors are likely to influence the decision to introduce a tax amnesty through several (sometimes conflicting) channels. A priori, the net effect of gubernatorial elections on the decision to introduce a tax amnesty is ambiguous - an empirical analysis is therefore warranted. On the one hand, since amnesties are a revenue source - as is raising taxes - they might similarly be frowned upon by state governors ahead of elections. ${ }^{9}$ On the other hand, since tax amnesties can, at least in the short term, be an alternative to increasing taxes as a revenue source, governors could be tempted to rely more often on amnesties during election years.

\footnotetext{
${ }^{8}$ Dubin, Graetz, and Wilde (1992) also investigate the effect, on the probability that a state declares an amnesty, of the Internal Revenue Service's (IRS's) audit rate. They find that, had the IRS's audit rate been constant rather than declining sharply as it was (and it has mostly continued to fall since 1992), states would have initiated far fewer amnesties. It is now recognized, however, that the sharp decline in IRS audit rates might only weakly be correlated with the effective detection capacity of the IRS since the IRS now relies much more on computerization which enables extensive cross checking and more targeted audits than was possible in the 1980s.

9 A large empirical political economy literature finds evidence that state governors running for re-election engineer a political-budget cycle, i.e., they have a tendency to increase spending and cut taxes ahead of elections, and reverse this behavior after elections (see Besley and Case, 2003, for recent evidence as well as a survey of the empirical literature).
} 


\section{Methodology: A Discrete-Time Duration Model}

The econometric model for modeling duration data we use is Cox. Cox's (Cox, 1972) semiparametric proportional hazard model provides a reasonable compromise between a purely empirical (i.e., non-parametric) approach to survival and hazard function estimation and the tight structure required by parametric models.

Cox's proportional hazards model is the following:

$$
h\left(t \mid x_{j}\right)=h_{0}(t) e^{x_{j} b}=h_{0}(t) e^{\left(b_{1} x_{1 j}+b_{2} x_{2 j}+. .+b_{k} x_{k j}\right)}
$$

where $h\left(t \mid x_{j}\right)$ is the probability that a tax amnesty occurs in state $\mathrm{j}$ any given year, conditional on the state not having introduced an amnesty before and on the control variables $\mathrm{x}_{\mathrm{j}}, h_{0}(t)$ is known as the baseline hazard, and $e^{x_{j} b}=e^{\left(b_{1} x_{1 j}+b_{2} x_{2 j}+\ldots+b_{k} x_{k j}\right)}$ is the relative hazard. $x_{j} b=b_{1} x_{1 j}+b_{2} x_{2 j}+. .+b_{k} x_{k j}$ is the log relative hazard (also known as the risk score).

The latter is assumed to be a function of the macroeconomic, fiscal, and political variables (these are detailed in the next section).

One important advantage of the Cox model over parametric duration models is that it does not assume any particular parameterization of the baseline hazard; ${ }^{10}$ that is, the model does not make any assumption about the shape of the hazard over time-it could be increasing, decreasing, constant, increasing then decreasing, etc. The only assumption made is that, whatever the shape of the hazard over time, it is the same for every U.S. state. Given the relatively low number of tax amnesties in the U.S. states, the tests of the validity of assumptions made on the shape of the hazard over time that are needed for parametric estimations are expected to have low power. ${ }^{11}$

\section{DATA DESCRIPTION}

The model measures the determinants of the time it takes for a state to declare its first tax amnesty, with 1977 being the starting year. A total of 596 state-years are analyzed with 48 U.S. states, 36 tax amnesties, and a mean time until the first tax amnesty of 12.4 years (with a minimum of 5 years and a maximum of 21 years). Once the first tax amnesty has occurred (i.e., the first "failure"), subsequent state data and therefore tax amnesties are not taken into consideration. The model does not therefore analyze the motives for repeated tax amnesty programs.

\footnotetext{
${ }^{10}$ Therefore, Cox's model does not produce any estimate of the baseline hazard $h_{0}(t)$.

${ }^{11}$ However, should we know (or be able to test with sufficiently high power) the functional form of $h_{0}(t)$, then the semi-parametric Cox model would be less efficient.
} 
The "escape/failure probability" (i.e., the probability of switching from having had no tax amnesty to having one in the current year) is assumed to be a function of the following macroeconomic and fiscal variables: the growth of a state's growth state product ("Growth"), total state taxes in millions of dollars ("Total taxes"), and the growth of a state's indebtedness ("Growth state debt"), and the following political variables: gubernatorial elections ("Election"), and whether an incumbent governor unsuccessfully runs for another term ("Governor defeated"). Detailed definitions and sources for these variables are in Table 1, while Table 2 provides summary statistics of these variables.

Table 1. Definitions and Sources of Variables Used

Amnesty 1/

Total taxes 2/

Growth 2/

Growth state debt 2/

Election 3/

Governor defeated 3/
Binary dummy variable (equals one if there is a tax amnesty)

Total state taxes collected (in millions of \$US)

Growth rate of per capita gross state product

Growth rate of total state debt

Gubernatorial elections binary dummy variable (equals one if there is a gubernatorial election)

Incumbent state governor defeated in re-election bid. Binary dummy variable (equals one if defeated)

1/ Source: The Federation of Tax Administrators.

2/ Source: U.S. Census Bureau, Statistical Abstract of the United States (various years).

3/ Source: The Book of the States, Council of State Governments (various years).

Table 2. Summary Statistics of Estimation Sample 1/

\begin{tabular}{lcrrrr}
\hline Variable & Units & Mean & $\begin{array}{c}\text { Standard } \\
\text { Deviation }\end{array}$ & Min. & Max. \\
\hline & & & & & \\
Total taxes & Millions of U.S. dollars & 629.7 & 158.3 & 231.1 & $1,070.3$ \\
Growth & Percentage & 6.9 & 4.0 & -14.1 & 25.1 \\
Growth state debt & Percentage & 14.8 & 26.1 & -35.0 & 347.3 \\
Election & Binary dummy variable & 0.29 & 0.46 & 0.0 & 1.0 \\
Governor defeated & Binary dummy variable & 0.09 & 0.28 & 0.0 & 1.0 \\
\hline
\end{tabular}

1/ Annual observations for 48 U.S. states starting in 1977. (Number of observations is 596.)

A state's gross state product (GSP) growth rate (or alternatively, a state's unemployment rate as these are highly correlated) is expected to be negatively related to the introduction of a tax amnesty program. Several channels are possible. First, because of the automatic fiscal stabilizers, a state experiencing an economic slowdown, will, ceteris paribus, experience a deterioration of its fiscal balance; this could increase the need for introducing a tax amnesty in order to raise short-term revenue. Second, during a recession, as financial hardship increases, noncompliance is also expected to increase (nonfiling, underreporting, etc.) which could increase the need for an amnesty so as to increase the tax base going forward. 
A state's total tax collection is expected to be positively related to the introduction of a tax amnesty program for several reasons. First, a large amount of tax collected — and its corollary: a large state government - is indicative of a large need for revenue and a large (in absolute amount) potential for evaded taxes. Second, a large state government has to be financed by relying on a large revenue collection which, ceteris paribus, requires higher tax rates than that of smaller governments. For a given detection probability and penalty structure, higher tax rates are more likely to increase noncompliance than lower rates. As absolute revenue and evaded taxes grow, at some point, a state might decide that the pool of evaded taxes has become sufficiently large as to warrant the introduction of a tax amnesty program so as to recapture some of the evaded money (the revenue yield motive).

The percentage change in a state's total debt is expected to be positively correlated with the introduction of a tax amnesty program. States that are experiencing a deterioration of their fiscal balance (and a growing state debt) might consider the introduction of a state tax amnesty as one way to increase revenue in the short-term and therefore limit the growth of state debt (the fiscal stress motive).

Theoretically, gubernatorial elections have an ambiguous effect on the decision to introduce a tax amnesty since several opposite channels are possible; the net effect, therefore, needs to be determined empirically. On the one hand, a negative and significant effect would provide evidence that state governors perceive taxes as another revenue source (akin to taxes): along with the well documented political budget cycles among U.S. states showing that governors do not introduce tax hikes during election years, ${ }^{12}$ this would provide a first evidence that they also shy away from amnesties during gubernatorial election years. Introducing a tax amnesty program ahead of a gubernatorial election could be politically unwise since, should the amnesty be successful, it would reveal to tax-abiding voters that they have been honestly paying their taxes but that the state government has not been successful at enforcing a basic taxation principle: that of horizontal equity. They could therefore blame the governor as being incompetent and not reelect him/her. In the case where an amnesty is unsuccessful, then the governor's reputation could also be tarnished by having introduced an unsuccessful program. On the other hand, a positive and significant effect would arise if governors think of tax amnesties and tax increases as substitutes. A tax amnesty program is not a new tax but an administrative scheme to collect past taxes. With tax increases ahead of elections being politically difficult, a given need for short-term revenue could be accomplished by introducing a tax amnesty program.

We expect that governors who decide to introduce a tax amnesty during an election year have a higher probability of being defeated than those who abstain from introducing an amnesty (i.e., we expect a positive and significant correlation between a defeated incumbent governor and a tax amnesty program). Tax amnesties may be perceived as unfair by law-abiding

\footnotetext{
${ }^{12}$ U.S. state governors have a tendency to increase (discretionary and highly visible) expenditures ahead of gubernatorial elections, and also to lower or not increase taxes ahead of elections (see Besley and Case (2003) for a survey of the literature and further evidence).
} 
taxpayers since tax evaders are being rewarded by financial incentives (e.g., a waiver of both penalties and interests on the tax liability, which implies, in real terms, a lower tax bill for tax evaders than for tax-abiding citizens). As a result, law-abiding taxpayers/voters might punish electorally a governor who declares a tax amnesty.

\section{EMPIRICAL RESUlTS}

We now turn to our empirical results from our panel data analysis of the determinants of the occurrence of tax amnesties in U.S. states from 1977 to 1998. Table 3 below shows the results of our Cox model with different control variables $\left(\mathrm{x}_{\mathrm{j}} \mathrm{s}\right)$ - the first column (Model 1), for instance, only controls for total state taxes as a determinant of the decision to introduce a tax amnesty, while the last column (Model 5) simultaneously controls for the effect of all the variables described above. Each coefficient measures the effect of a one unit change of the explanatory variable. A hazard ratio greater (lesser) than 1.0 indicates an increase (decrease) in the probability of a tax amnesty occurring. The table reveals that, controlling for the level of a state's total tax revenue and the gross state product's growth rate, a tax amnesty program has:

- a significantly higher probability of being declared in states where debt is increasing;

- a significantly lower probability of being declared (by a state governor) during a year when gubernatorial elections are held; and

- a significantly higher probability of being declared when an incumbent governor was allowed to run for re-election but lost the election.

These results hold in all our specifications, and the magnitude and significance of the coefficients are, quite surprisingly so, stable across all our specifications. They extend and confirm some of the earlier results on DGW (1992). As do DGW, we find supportive evidence that states with high tax levels are slightly more likely to initiate a tax amnesty (see Models 1 and 2 in Table 3); a one million dollar increase in total state taxes is found to increase the hazard of a tax amnesty by 0.2 percent.

However, in contrast with DGW, we find that even controlling for the revenue yield effect (and a state's growth rate), tax amnesties are more likely to be declared when a state is experiencing a growing budget deficit. A 1 percentage point increase in state debt increases the hazard of a tax amnesty by about 2 percent (Model 3 in Table 3). Tax amnesties are therefore viewed as a revenue-raising source.

An especially striking result is that we are able to resolve a theoretically ambiguous effect regarding the effect of political considerations on the timing of tax. We find that policymakers perceive tax amnesties as another form of revenue source (the election variable as a negative and significant coefficient in Model 4 of Table 3) rather than as an alternative to a tax increase. Similar to the well-known aversion to increase taxes ahead of elections, state governors are far less likely to declare a tax amnesty during a gubernatorial 
election year: we find that tax amnesties are about 50 percent less likely to occur in election years.

We also find evidence supporting the view that tax amnesty programs are perceived by voters as "unfair" to them since they reward tax evaders with a lower effective tax rate than that of law-abiding tax payers (thereby breaking horizontal equity). Model 5 in Table 3 shows that state governors who ran for another term but lost their reelection bids were more than twice as likely to offer a tax amnesty during their election years.

Table 3. Model for Time Waited Before Initiating a State Tax Amnesty

\begin{tabular}{llllll}
\hline Variables: & Model 1 & Model 2 & \multicolumn{1}{c}{ Model 3 } & \multicolumn{1}{c}{ Model 4 } & \multicolumn{1}{c}{ Model 5 } \\
\hline Total state taxes & 1.002 & 1.002 & 1.002 & 1.002 & 1.003 \\
& $(0.001)^{*}$ & $(0.001)^{* *}$ & $(0.001)^{* *}$ & $(0.001)^{* * *}$ & $(0.001)^{* * *}$ \\
Growth & & 0.909 & 0.901 & 0.891 & 0.906 \\
& & $(0.049)^{*}$ & $(0.052)^{*}$ & $(0.044)^{* *}$ & $(0.046)^{*}$ \\
Growth state debt & & & 1.017 & 1.017 & 1.018 \\
& & & $(0.007)^{* * *}$ & $(0.004)^{* * *}$ & $(0.005)^{* * *}$ \\
Election & & & 0.520 & 0.530 \\
& & & & $(0.181)^{*}$ & $(0.179)^{*}$ \\
Governor defeated & & & & 2.50 \\
& & & & & $(0.81)^{* * *}$ \\
& & & & & \\
Log likelihood & -121.3 & -120.0 & -117.7 & -116.7 & -115.1 \\
Number of observations & 596 & 596 & 596 & 596 & 596 \\
\hline
\end{tabular}

Notes: Hazard ratio (standard errors). The hazard ratio measures the effect of a one unit change of the explanatory variable. A hazard ratio greater (lesser) than 1.0 indicates an increase (decrease) in the probability of a tax amnesty occurring.

* denotes statistical significance at 10 percent level; ** denotes statistical significance at 5 percent level; and $* * *$ denotes statistical significance at 1 percent level.

\section{CONCLUSION}

In this paper, we have revisited some of the early results on the determinants of tax amnesty programs in the U.S. states. Our aim was twofold: first, to assess whether those determinants have been stable over time; and, second, building on the recent political economy literature, we check whether political — rather than purely economic - factors have a bearing on the introduction of tax amnesty programs.

Similar to earlier empirical studies (e.g., Dubin, Graetz, and Wilde, 1992), we find that states with high tax levels are more likely to initiate a tax amnesty. In contrast to earlier studies, however, we also find that in our broader sample, even controlling for the revenue-yield effect (and a state's growth rate), tax amnesties are more likely to be declared when a state's indebtedness is growing. Tax amnesties are, therefore, viewed as a revenue-raising source. 
A key novelty of this paper's analysis is that (i) it shows not only that political factors significantly affect the introduction and timing of tax amnesties, but also, and strikingly, that (ii) the empirical results manage to clearly disentangle opposite theoretical political economy effects. The results support the view that state governors perceive tax amnesties as another form of revenue source (and not as an alternative to raising taxes). In particular, we find that consistent with well-known aversion to increasing taxes ahead of elections, governors are only half as likely to declare a tax amnesty during election years. This study also finds supportive evidence that law-abiding taxpayers/voters might consider a tax amnesty as unfair to them and would electorally punish governors who offered tax amnesties: governors who run for another term but lost their reelection bids were more than twice as likely to have offered a tax amnesty during their election years. 


\section{REFERENCES}

Allingham, M.G., and A. Sandmo, 1972, "Income Tax Evasion: A Theoretical Analysis," Journal of Public Economics, Vol. 1, pp. 323-38.

Alm, J., and W. Beck, 1993, "Tax Amnesties and Compliance in the Long Run: A Time Series Analysis," National Tax Journal, Vol. 46, pp. 53-60.

Alm, J., M. McKee, and W. Beck, 1990, “Amazing Grace: Tax Amnesties and Compliance,” National Tax Journal, Vol. 43, pp. 23-37.

Andreoni, J., 1991, "The Desirability of a Permanent Tax Amnesty," Journal of Public Economics, Vol. 45, pp. 143-59.

- B. Erard, and J. Feinstein, 1998, "Tax Compliance," Journal of Economic Literature, Vol. 36, pp. 818-60.

Besley, T., and A. Case, 2003, "Political Institutions and Policy Choices: Evidence from the United States," Journal of Economic Literature, Vol. 41(1), pp. 7-73.

Christian, C.W., S. Gupta, and J.C. Young, 2002, "Evidence on Subsequent Filing From the State of Michigan's Income Tax Amnesty,"National Tax Journal, Vol. 55, pp. 703-21.

Cox, D., 1972, "Regression Models and Life Tables," Journal of The Royal Statistical Society, Series B, Vol. 34, pp. 187-220.

Dubin, J.A., M. Graetz, and L.L. Wilde, 1992, "State Income Tax Amnesties: Causes," Quarterly Journal of Economics, Vol. 107, pp. 271-83.

Franzoni, L.A., 1995, On the Economics of Tax Amnesties, D.Phil. Thesis, Nuffield College, Oxford. [Chapter 2 is a detailed review of experiences of different countries.]

Graetz, M., and L. Wilde, 1993, "The Decision by Strategic Nonfilers to Participate in Income Tax Amnesties," International Review of Law and Economics, Vol. 13, pp. 271-83.

Joulfaian, D., 1988, "Participation in Tax Amnesties: Evidence from a State," in Proceedings of the Eighty-First Annual Conference on Taxation, National Tax Association, Washington DC, pp. 128-32.

Leonard, H.B., and R. Zeckhauser, 1987, “Amnesty, Enforcement, and Tax Policy," in Tax Policy and the Economy, ed. by Lawrence Summers (Cambridge, Massachusetts: MIT Press). 
Malik, A.S., and R.M. Schwab, 1991, "The Economics of Tax Amnesties," Journal of Public Economics, Vol. 46, pp. 29-49.

Stella, P., 1991, “An Economic Analysis of Tax Amnesties," Journal of Public Economics, Vol. 46, pp. 383-400.

Torger, B., and C.A. Schaltergger, 2005, "Tax Amnesties in Switzerland and Around the World," Tax Notes International, June 27, pp. 1193-1203.

United States, Congress, Joint Committee on Taxation, 1998, “Tax Amnesties," January 30. 